open 2 access

\title{
Pasung of Schizophrenic patients in Pekanbaru City
}

\author{
Richie Futrawan (D), Mustafa M. Amin*(D), Elmeida Effendy (D) \\ Department of Psychiatry, Faculty of Medicine, Universitas Sumatera Utara, Medan, Indonesia
}

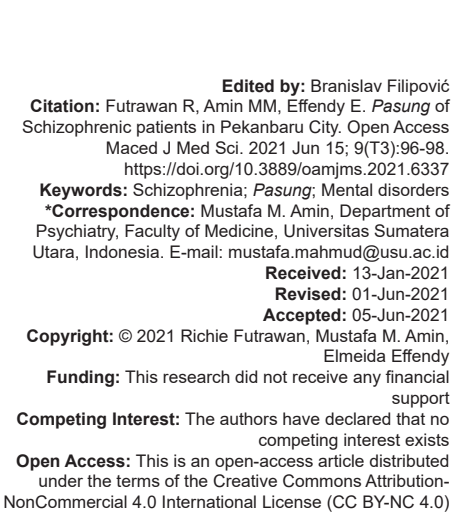

\section{Abstract}

BACKGROUND: Pasung is an act using a block of wood on someone's hands and/or feet, tied or chained, exiled in a separate place in the house or in the forest. Mental disorders are still a serious mental health problem in Indonesia. There are still many schizophrenics who do not receive medical treatment or who drop out of medical treatment and eventually put in a Pasung.

CASE REPORT: We found several cases of patients with schizophrenia who were incarcerated, men aged 43 years and 40 years. They were diagnosed with schizophrenia with different characteristics of the disorder, different treatments, and in the end the Pasung became the last alternative completed by the family.

CONCLUSION: Ignorance of the family and surrounding community over the early detection and forced treatment at the Mental Hospital (asylum), causing patients not handled properly. It is only culturally known by the family to handle it, Pasung that is to prevent people with severe mental disorders from endangering themselves and others.

\section{Introduction}

Schizophrenia is a psychotic condition commonly characterized by distortion of fundamental and distinctive thoughts and beliefs and an inappropriate or blunted effect. Clear memory and analytical skills are typically preserved, although certain cognitive disabilities can develop later. The most basic functions that give normal individuals a sense of identity (individuality), uniqueness, and self-direction are involved in this condition. The most intimate/deep thoughts, emotions, and actions frequently feel understood or communicated with others, and understandings may emerge, explaining that the thoughts and actions of sufferers are influenced by natural and supernatural forces at work in ways that often do not come to the meaning or bizarre [1], [2], [3], [4].

Schizophrenia is a commonly occurring psychotic condition, with a risk of around $1 \%$, the age of $15-30$ years is the most common initial onset of this illness, which is a persistent disease that causes interference with patients and their families and causes interference with patients and their families, as well as having a significant effect on their social and economic situation. The prevalence of schizophrenia in men and women at the start of the first attack is the same but different. Men between 10-25 years of age and 25-35 years of age have the highest attacks among women. Of the $90 \%$ of patients between the ages of 15-55 who undergo schizophrenia treatment. Onset below 10 years or above 60 years of age is seldom published. Females with schizophrenia have better performance in general than males [1], [2], [3], [4].

Several studies have sub-categories of symptoms of this disease into five parts, namely: Positive symptoms, negative symptoms, cognitive symptoms, aggressive symptoms, and symptoms of depression/anxiety [1], [2], [3], [4].

\section{Positive symptoms}

Suspicion, hallucinations, jumbled ideas, disorganized speech, catatonic behavior and agitation. All of these positive symptoms were found in diagnostic criteria of schizophrenia [1]. We identified the symptoms above and reported by the patients family.

\section{Negative symptoms}

Blunt affect, emotional withdrawal, poor rapport, ignorance, self-withdrawal from social life, disruption of abstract thinking, alogia, avolition, anhedonia, and distraction. Negative symptoms were defined as reduced of normal functioning. These symptoms were thought to be difficult to treat in schizophrenia [3].

\section{Cognitive symptoms}

Thought disorders, incoherence, loose associations, neologisms, and information processing 
disorders. Cognitive symptoms were considered as an important part in schizophrenic symptoms as well as positive and negative symptoms [3]. We found these symptoms when we conducted the psychiatric interview for the patient in our report.

\section{Aggressive symptoms}

Hostility, verbal insults, physical violence, selfinjury, property damage, impulsive, and sexual acts. Some authors considered that aggressive symptoms as one of the five symptoms domain in schizophrenia, and these symptoms were found in the patient we report below [3].

\section{Depression/anxiety symptoms}

Depressed mood, anxious mood, feelings of guilt, tension, and irritability [3], [4]. As well as the other symptoms, depression/anxiety symptoms were included in one of the symptoms domain in schizophrenia [3].

Pasung in Indonesia has been a long-standing problem. There are about $20,000-30,000$ people with mental disorders throughout Indonesia who received treatment in pairs (Purwoko, 2010). Pasung is an act of using a block of wood on a person's hands and/or feet, tied or chained, exiled in a separate place in the house or the forest [5], [6].

Pasung can also be defined as an act of limiting the movement of a person suffering from impaired mental function and behavior by means of physical restraint for an indefinite period of time which causes limited fulfillment of basic needs of a decent life, including health, education, and employment for that person [6], [7].

\section{Case Report}

MR. RY is 43 years old. Having schizophrenic has 8 years. He has a history of often attacking other people and likes to chase after women in his villages. Mr. RY has three young children. His wife adrift to a rather distant age with him that is 28 years old. Two years ago, Mr. RY was relieved of his job. His wife and their children find it difficult to care for Mr. RY. Incidentally, his residence in a remote area far from mental health facilities. One day Mr. RY went berserk and set fire to the house of one of his neighbors. Mr. RY accused his neighbors of causing him to be fired from his job. Mr. RY threatened to kill his neighbor, In conclusion, his wife made Pasung from wooden blocks behind their house. Mr. RY already got Pasung for 8 years in a sad situation.

MR. N is 40 years old, who does not have enough education, from well-off families, who is not married and live in the countryside. The early history, he is normal up to middle school and tends to be clever nevertheless lacks communication with the surroundings. While MR. N went to Vocational School he has been scolded by his teacher. Starting from this incident triggered mental disorders at the time of Mr. N to drop out of school. Mr. N's family took treatment to a mental hospital and treated it until it was better. After getting better, Mr. $\mathrm{N}$ was returned to his family. Next 1 year, his mother passed away. Following this event, his mental disorders coming back and more aggressive. His family thought to bring him in getting admission to mental hospital. Having heard from people around that Mr. $\mathrm{N}$ was poorly treated in the asylum, Mr. N's father brought him home and did traditional medicine and was put in a Pasung. Mr. $\mathrm{N}$ has been Pasung up for 20 years in a state of sadness.

\section{Discussion}

In establishing the diagnosis of a type of disease should know several diagnostic criteria for schizophrenia based on PPDGJ-III, ICD-10, and DSM-5 are as follows: [4], [8], [9]

Schizophrenic disorders based on PPDGJ-III are generally characterized by distortions of the mind and perceptions that are fundamental and distinctive and by an inappropriate or blunted affect. Clear awareness and intellectual ability are maintained, although certain cognitive deficits can develop later. Although there are no specific pathognomonic symptoms, in practice, it is useful to divide the symptoms into groups which are often present together, for example: [4], [8], [9]

a. "thought echo," "thought insertion" "withdrawal" and "thought broadcasting"

b. Delusion of control, delusion of influence or passivity which clearly refers to bodily movements or movements of limbs, or thoughts, actions or feelings (sensation) special; delusional perception

c. The sound hallucinations constantly commenting on the behavior of the patient, or the patient discuss the matter among themselves, or other types of hallucinatory voices coming from one part of the body

d. Supposition-delusion settling other types according to their culture is considered unnatural and completely impossible, such as the religious identity or politics, or the power and capabilities of the "Superman" (e.g., being able to control the weather or communicate with aliens from another world)

e. Permanent hallucinations in each modality, if accompanied by both floating and half-shaped delusions without clear affective content, or by persistent over-valued ideas, or if they occur every day for weeks or months continuously

f. Interrupted or interpolated thoughts that result in incoherence or irrelevant speech, or neologism, catatonic behavior, such as 
excitement, posture, or flexibility in cereals, negativism, mutism, and stupor

g.

"Negative" symptoms such as apathy, stalled speech, and emotional responses that are dull or unnatural, usually resulting in withdrawal from social intercourse and decreased social performance, but it must be clear that all of these things not caused by depression or neuroleptic medication. A consistent and meaningful change in the overall quality of several aspects of individual behavior manifests as loss of interest, aimlessness, laziness, self-absorbed attitude, and social withdrawal

Pasung client characteristics include age, mental illness duration, medical treatment routine, number of recurrences, Pasung condition, and length of Pasung [6], [7].

Based on the case report above, after a complete psychiatric history, clinical interview, psychological test, and mental status examination and refer to the diagnostic criteria for schizophrenia based on PPDGJ-III, ICD-10, and DSM-5 [4], [8], [9].

When classified based on the classification of schizophrenia on the criteria of the Pasung client, then the case report is in accordance with the characteristics of the Pasung client. The results of the analysis of the characteristics of the age showed a significant relationship between the age of the client Pasung with social aspects. Age is closely related to the level of maturity. Adulthood is the stage of putting oneself in society and taking responsibility for whatever is produced by the community. The above statement supports the examination results which show that the average age of Pasung clients is starting from 35 years [4], [7]

Schizophrenia classification based on client characteristics Pasung based on the length of time suffering from a mental disorder shows the frequency will have an impact on the delay in achieving ability and independence [5], [6].

Schizophrenia based on client characteristics Pasung based on routine medical treatment showed a meaningful relationship between routine medical treatment with social aspects. This result is supported by Xiong et al. (1994) on 64 schizophrenia patients in China who were randomly divided into two groups: The intervention group getting family psychoeducation and drugs, and the control group only getting drugs. From both groups, the group that received psychoeducation and drugs got more positive results [6], [7].

Schizophrenia based on client Pasung characteristics based on the number of recurrences shows no significant relationship with social, especially if the patient routinely takes medication so that recurrence can be minimized [7]. Schizophrenia classification based on client characteristics Pasung based on length of Pasung shows that the dipping is done if the patient is in a state of severe disruption. According to interviews with clients' families, the majority of clients are Pasung because the client is trying to hurt the family and others [6].

\section{Conclusion}

Based on research, it was found that sufferers suspected of suffering from psychiatric disorders were put on more by families as a last alternative for handling mental disorders after all medical treatment efforts were carried out by families. However, the ignorance of the family and the community around early detection and forced treatment of treatment at the Mental Hospital caused the patient was not appropriately handled. It is only culturally known by the family to handle it, that is, to prevent people with severe mental disorders from endangering themselves and others. Besides, it is a way for families to be able to oversee for people with severe mental disorders (around the environment).

\section{References}

1. Sadock BJ, Sadock VA, Ruiz P. Schizophrenia. In Kaplan and Sadock's Synopsis of Psychiatry Behavioral Sciences/Clinical Psychiatry. $11^{\text {th }}$ ed. Philadelphia, PA: Lippincott Williams \& Wilkins; 2015. p. 649-701. https://doi. org/10.1097/00004850-198907000-00008

2. Iriondo MR, Salaberria K, Echeburua E. Schizophrenia: Analysis and psychological treatment according to the clinical staging. Actas Esp Psiquiatr. 2013;41(1):52-9.

PMid:23440536

3. Stahl SM. Psychosis and schizophrenia. In: Stahl's Essential Psychopharmacology: Neuroscientific Basis and Practical Application. $4^{\text {th }}$ ed. Cambridge: Cambridge University Press; 2013. p. 79-128.

4. Departemen Kesehatan Republik Indonesia, Direktorat Jenderal Pelayanan Medik. Pedoman Penggolongan dan Diagnosis Gangguan Jiwa di Indonesia III (PPDGJ III), Jakarta; 1993.

5. Kusumadewi AF, Kristanto CS, Sumarni DW. Bebas pasung: Ditinjau dari aspek bioetika. J Psikiatri Indones. 2016;1(1):1. [Last accessed on 08 Sep 2020].

6. Laila NH, Mahkota R, Krianto T, Shivalli S. Perceptions about pasung (physical restraint and confinement) of schizophrenia patient: A qualitative study among family members and other key stakeholders in Bogor Regency, West Java Province, Indonesia 2017. BMC. 2018;12:35. https://doi.org/10.1186/ s13033-018-0216-0

7. Minas H, Diarti H. Pasung: Physical restraint and confinement of the mentally ill in the community. Int $\mathrm{J}$ Ment Health Syst. 2008;2(1):8. https://doi.org/10.1186/1752-4458-2-8 PMid:18554420

8. World Health Organization. ICD-10 Version: 2016. Geneva: World Health Organization; 2016.

9. American Psychiatric Association. Diagnostic and Statistical Manual of Mental Disorders: DSM-5. Philadelphia, PA: American Psychiatric Association; 2013. https://doi.org/10.1007/ springerreference_179660 